\title{
ASPECTOS ACERCA DA RESPONSABILIDADE NOS CONTRATOS DE PROMESSA DE COMPRA E VENDA DE BEM IMÓVEL: INCIDÊNCIA DO CÓDIGO DE DEFESA DO CONSUMIDOR E DO CÓDIGO CIVIL
}

\author{
Felipe Cunha de Almeida ${ }^{1}$
}

\section{INTRODUÇÃO}

São pacíficos os transtornos causados pelo atraso na entrega de uma obra. Os consumidores economizam valores, planejam uma vida nova em uma nova residência, desfazem-se de alguns bens para dar a entrada necessária, assumem financiamentos, tudo no sentido de aguardar o que foi contratado. Mas, em muitos casos, tal atraso repercute negativamente na vida dos compradores, a inexecução do contrato pelo vendedor é extremamente prejudicial e, inevitavelmente, as ações de rescisão de contrato de promessa de compra e venda de bem imóvel acabam batendo às portas do Poder Judiciário, com o objetivo de indenizações e ressarcimentos, em face de tal fato.

A análise da incidência das normas do Código de Defesa do Consumidor, quando presente o consumidor e o fornecedor ${ }^{2}$, bem como as disposições do Código Civil e da Lei 4.591/64, é imprescindível para a resolução dos problemas envolvendo esse tipo de contratação. Portanto, veremos a responsabilidade do construtor, do incorporador, bem como alguns tipos de indenizações e ressarcimentos, que

1 Mestrando pela Universidade Federal do Rio Grande do Sul, professor, advogado, especialista em Direito Processual Civil em Porto Alegre/RS.

2 FILHO, Sérgio Cavalieri. Programa de direito do consumidor. São Paulo: Atlas, 2010, 2. ed., p. 243. 
a Justiça vem concedendo aos prejudicados, em decorrência do atraso na entrega de obras. Ainda, além do entendimento doutrinário, será trazido o entendimento do Tribunal de Justiça do Rio Grande do Sul, bem como do Superior Tribunal de Justiça acerca da matéria.

O objetivo deste artigo, portanto, é contribuir para que os operadores do Direito, os consumidores e empresários tenham exata noção acerca da importância de um contrato de incorporação, de construção, bem como sobre a responsabilidade inerente a tal empreendimento. Objetiva também, pela inobservância das obrigações que devem ser seguidas, mostrar que fatalmente haverá condenações aos responsáveis.

\section{CONTRATO DE INCORPORAÇÃO IMOBILIÁRIA}

Os contratos de construção, assim como os demais, estão sujeitos às diretrizes do Código Civil de 2002: boa-fé objetiva e probidade, exercício de direito dentro dos limites da lei, liberdade de contratar em razão e nos limites da função social do contrato (deve representar uma justa composição entre os direitos individuais e coletivos). ${ }^{3} \mathrm{~A}$ definição de incorporação e da figura do incorporador é dada pela Lei n. 4.591/64 $4^{4}$, em seus artigos 28 e 29.

\subsection{A irretratabilidade dos contratos de incorporação}

Em se falando de contrato de incorporação, a irretratabilidade é a regra. Todavia, para o incorporador, há prazo de cento e oitenta dias [Lei n. 4.864/65, que Cria Medidas de estímulo à Indústria de Construção Civil. art. 12. Fica elevado para 180 (cento e oitenta) dias o prazo de validade de registro da incorporação a que se refere] para renunciar à incorporação, iniciando o prazo com o registro, e refletir, também, sobre os contratos de transferência de frações ideais já realizadas. Outra previsão para a rescisão por iniciativa dos compradores é no tocante à falência ou insolvência, paralisação ou demora injustificada da obra, de acordo com o artigo 43 da Lei de n. 4.594/64. Havendo a mora do adquirente ou promitente vendedor da unidade, deve haver a notificação

3 MEIRELLES, Hely Lopes. Direito de construir. São Paulo: Malheiros, 2011, 10a ed., p. 235-236.

4 FILHO, Sérgio Cavalieri. Programa de direito do consumidor. São Paulo: Atlas, 2010, 2. ed., p. 243. 
para saldar o débito, no prazo de quinze dias, sob pena de resolução.

É importante ressaltar que, em relação à incorporação, afora as hipóteses mencionadas, não cabe a rescisão, como já dito. A inadimplência do adquirente acarreta a rescisão do contrato, e não da incorporação, ocorrendo a substituição através da venda da unidade a outra pessoa, ou venda em leilão. Todavia, ensina Arnaldo Rizzardo que a resilição pura e simples é vedada, eis que a desistência do negócio seja quais forem as razões invocadas, como desinteresse, mudança de residência, falta de condições econômicas ou a superveniência da impossibilidade econômica. Aduz o autor que essa é a melhor exegese, eis que é o tratamento normal a todos que adquirem bens. Mas, por outro lado, pondera que a jurisprudência tem relevado a questão dos desistentes, impondo apenas a retenção de parcela, com o objetivo de cobrir custos, despesas e prejuízos que o vendedor suportará. ${ }^{5}$

\subsection{A construção e a responsabilidade}

Três fontes acarretam na responsabilidade: a lei (responsabilidade legal), o contrato (responsabilidade contratual), e o ato ilícito (responsabilidade extracontratual). ${ }^{6}$

\subsection{Causas que isentam a responsabilidade}

Para os casos de exclusão da responsabilidade, o CDC é taxativo, e as hipóteses são previstas no artigo 12, $\S 3^{\circ}$. Em todas as hipóteses marcadas pelo Código, as causas para a exclusão devem quebrar o nexo de causalidade, devem desconstituí-lo, comprovando a ausência de nexo entre a conduta do fornecedor e o dano suportado pelo consumidor. $^{7}$

Entretanto, quanto ao caso fortuito e força maior, se seriam ou não excludentes da obrigação de indenizar, o Código de Defesa do Consumidor

5 RIZZARDO, Arnaldo. Condomínio edilício e incorporação imobiliária. Forense: Rio de Janeiro, 2. ed., 2012, p. 285.

6 MEIRELLES, Hely Lopes. Direito de construir. São Paulo: Malheiros, 2011, 10. ed., p. 285-286.

7 MIRAGEM, Bruno. Curso de direito do consumidor. São Paulo: Revista dos Tribunais, 3. ed., 2012, p. 451. 
mostra-se silente ao tema. A doutrina, por sua vez, é dividida. Aqueles que defendem a impossibilidade de exclusão da responsabilidade em razão do caso fortuito ou força maior aduzem que as hipóteses elencadas nos artigos 12 e 14 são taxativas, portanto, não podem ser alvo de ampliação por interpretação. Em contrapartida, aqueles que defendem a incidência do caso fortuito e da força maior fundamentam a posição no sentido de que se trata de teoria geral da responsabilidade civil. ${ }^{8}$

Aspecto fundamental é no tocante à possibilidade ou impossibilidade de reconhecimento, ou não, do caso fortuito ou da força maior, como excludentes da responsabilidade pelo fato do produto ou do serviço. O Código Civil, em seu artigo 393, determina que o devedor não responde pelos danos, prejuízos, decorrentes do caso fortuito ou força maior. Todavia, tais excludentes não constam no rol dos artigos $12^{\circ} 3^{\circ}$, e $14 \S 3$ do Código de Defesa do Consumidor. No direito civil, o caso fortuito ou a força maior afastam a imputação da responsabilidade. ${ }^{9}$
Sem adentrarmos em polêmica quanto à diferenciação do significado entre caso fortuito e força maior, existe concordância, perante a doutrina, de que o caso fortuito possui, basicamente, duas características essenciais: a necessariedade e a inevitabilidade. Não exige, ainda, que seja imprevisível. Por outro lado, a força maior é entendida como dotada de externidade e inevitabilidade, não se distinguindo plenamente do caso fortuito. Nos dias atuais, tanto a doutrina como a jurisprudência estabelecem outra distinção referente ao caso fortuito, para a exclusão da responsabilidade, diferenciando o caso fortuito interno do caso fortuito externo. Quanto a esse último, existe admissibilidade sobre a exclusão da responsabilidade. ${ }^{10}$

O caso fortuito interno consiste em um fato inevitável e imprevisível que está intimamente ligado à atividade do agente. Portanto, no exercício da autonomia privada, deve arcar com os riscos inerentes a tanto. Já o caso fortuito externo é determinado fato estranho à organização ou ati-

8 MIRAGEM, Bruno. Curso de direito do consumidor. São Paulo: Revista dos Tribunais, 3. ed., 2012, p. 451.

9 MIRAGEM, Bruno. Curso de direito do consumidor. São Paulo: Revista dos Tribunais, 3. ed., 2012, p. 459.

10 MIRAGEM, Bruno. Curso de direito do consumidor. São Paulo: Revista dos Tribunais, 3. ed., 2012, p. 459-460. 
vidade empresarial. Em razão disso, não tem seus riscos suportados por ela. ${ }^{11}$

Vejamos a orientação do Superior Tribunal de Justiça. Bruno Miragem, em referência ao REsp n. 330.523/
$\mathrm{SP}^{12}$ pondera que, no Código de Defesa do Consumidor, existe uma tendência em se admitir o caso fortuito e a força maior como excludentes da responsabilidade do fornecedor. Trazemos outro julgado. ${ }^{13}$

11 MIRAGEM, Bruno. Curso de direito do consumidor. São Paulo: Revista dos Tribunais, 3. ed., 2012, p. 460.

12 Ementa: Ação de indenização. Estacionamento. Chuva de granizo. Vagas cobertas e descobertas. Art. 1.277 do Código Civil. Código de Defesa do Consumidor. Precedente da Corte.

Como assentado em precedente da Corte, o "fato de o artigo 14, $\S 3^{\circ}$ do Código de Defesa do Consumidor não se referir ao caso fortuito e à força maior, ao arrolar as causas de isenção de responsabilidade do fornecedor de serviços, não significa que, no sistema por ele instituído, não possam ser invocadas. Aplicação do artigo 1.058 do Código Civil" (REsp n ${ }^{\circ}$ 120.647-SP, Relator o Senhor Ministro Eduardo Ribeiro, DJ de 15/05/00).

Havendo vagas cobertas e descobertas é incabível a presunção de que o estacionamento seria feito em vaga coberta, ausente qualquer prova sobre o assunto.

Recurso especial conhecido e provido.

(RECURSO ESPECIAL N 330.523 - SP (2001/0090552-2), Rel. Min. Ari Pargendler, $3^{\text {a }}$ Turma, julgado em 11/12/2001). Disponível em:< https://ww2.stj.jus.br/websecstj/ cgi/revista/REJ.cgi/IMG?seq=21403\&nreg=200100905522\&dt=20020325\&formato= HTML>. Acesso em: 10 maio 2013.

13 CIVIL E PROCESSUAL CIVIL. RESPONSABILIDADE CIVIL. TRANSPORTE DE PESSOAS. CASO FORTUITO. CULPA DE TERCEIRO. LIMITES. APLICAÇÃO DO DIREITO À ESPÉCIE. NECESSIDADE DE REEXAME DE PROVA. IMPOSSIBILIDADE.

1. A cláusula de incolumidade é ínsita ao contrato de transporte, implicando obrigação de resultado do transportador, consistente em levar o passageiro com conforto e segurança ao seu destino, excepcionando-se esse dever apenas nos casos em que ficar configurada alguma causa excludente da responsabilidade civil, notadamente o caso fortuito, a força maior ou a culpa exclusiva da vítima ou de terceiro.

2. O fato de um terceiro ser o causador do dano, por si só, não configura motivo suficiente para elidir a responsabilidade do transportador, sendo imprescindível aferir se a conduta danosa pode ser considerada independente (equiparando-se a caso fortuito externo) ou se é conexa à própria atividade econômica e aos riscos inerentes à sua exploração.

3. A culpa de terceiro somente romperá o nexo causal entre o dano e a conduta do transportador quando o modo de agir daquele puder ser equiparado a caso fortuito, isto é, quando for imprevisível e autônomo, sem origem ou relação com o comportamento da própria empresa. 
Embora haja debate na doutrina acerca do ponto em discussão, ainda que o Direito do Consumidor acate a diferença entre o caso fortuito interno e o externo, só será considerado como excludente de responsabilidade do fornecedor o caso fortuito externo, quando o evento causador do dano é estranho à atividade típica do fornecedor, rompendo, de tal forma, o nexo causal. ${ }^{14}$ Importante a leitura dos acórdãos AGRG no AG 516.847/RJ ${ }^{15}$ e do REsp 685.662/ RJ. ${ }^{16}$

4. Na hipótese em que o comportamento do preposto da transportadora é determinante para o acidente, havendo clara participação sua na cadeia de acontecimentos que leva à morte da vítima - disparos de arma de fogo efetuados logo após os passageiros apartarem briga entre o cobrador e o atirador -, o evento não pode ser equiparado acaso fortuito.

5. Quando a aplicação do direito à espécie reclamar o exame do acervo probatório dos autos, convirá o retorno dos autos à Corte de origem para a ultimação do procedimento de subsunção do fato à norma. Precedentes.

6. Recurso especial provido. (REsp 1136885 SP 2009/0078922-7, Rel Min. NANCY ANDRIGHI, $3^{\text {a } T u r m a, ~ j u l g a d o ~ e m ~ 28 / 02 / 2012) . ~ D i s p o n i ́ v e l ~ e m:<h t t p: / / w w w . j u s b r a s i l . c o m . ~}$ br/jurisprudencia/21384762/recurso-especial-resp-1136885-sp-2009-0078922-7-stj>. Acesso em: 02 maio 2013.

14 MIRAGEM, Bruno. Curso de direito do consumidor. São Paulo: Revista dos Tribunais, $3^{\mathrm{a}}$ ed., 2012, p. 461.

15 Ementa: PROCESSO CIVIL - AGRAVO DE INSTRUMENTO - NEGATIVA DE PROVIMENTO - AGRAVO REGIMENTAL - INDENIZAÇÃO POR DANOS MORAIS - ASSALTO À MÃO ARMADA NO INTERIOR DE ÔNIBUS COLETIVO CASO FORTUITO - EXCLUDENTE DE RESPONSABILIDADE DA EMPRESA TRANSPORTADORA - SÚMULA 83/STJ - DESPROVIMENTO.

1. Este Tribunal já proclamou o entendimento de que, fato inteiramente estranho ao transporte (assalto à mão armada no interior de ônibus coletivo), constitui caso fortuito, excludente de responsabilidade da empresa transportadora. Precedentes (REsp $\mathrm{n}^{\circ} \mathrm{S}$ 402.227/RJ, 435.865/RJ e 264.589/RJ ).

2. Aplicável, portanto, à hipótese, o enunciado sumular de no $83 / \mathrm{STJ}$.

3. Agravo Regimental conhecido, porém, desprovido.

(AgRg no AGRAVO DE INSTRUMENTO No 516.847 - RJ, Rel. Min. Jorge Scartezzini, $4^{a}$ Turma, julgado em 14/09/2004). Disponível em:< https://ww2.stj.jus.br/processo/ jsp/revista/abreDocumento.jsp?componente $=$ ITA\&sequencial=497207\&num_registro $=200300703520 \&$ data=20041108\&formato $=H T M L>$. Acesso em: 10 maio 2013.

16 Direito processual civil e do consumidor. Recurso especial. Roubo de talonário de cheques durante transporte. Empresa terceirizada. Uso indevido dos cheques por terceiros posteriormente. Inscrição do correntista nos registros de proteção ao crédito. Responsabilidade do banco. Teoria do risco profissional. Excludentes da responsabilidade do fornecedor de serviços. art. 14, § $3^{\circ}$, do CDC. Ônus da prova. 


\subsection{A responsabilidade dos adquirentes no financiamento hipotecário da construção}

Questão importante, também, é no tocante à frequência com que o incorporador contrai empréstimo ou financiamento para a construção, oferecendo em garantia o próprio imóvel ou a construção, por meio de hipoteca ou alienação fiduciária. Assim, em geral, o preço é financiado pelo próprio incorporador, e o restante por instituição financeira. ${ }^{17}$ De acordo com a Súmula 308 do Superior Tribunal de Justiça, o adquirente não é prejudicado. ${ }^{18}$

\section{OBRIGAÇÕES DO INCORPORADOR}

A legislação obriga o incorporador a entregar o prédio de acordo com o que foi estabelecido no projeto de construção, bem como no memorial descritivo. ${ }^{19}$ Portanto, a obrigação e responsabilidade do incorporador decorrem, além do contrato, da própria lei. Deve ser observada a fidelidade ao prometido, vedada a fuga unilateral dos termos da vença. O incorporador, dessa feita, é o responsável por qualquer tipo de dano que resulte da inexecução ou da má execução (entrega

- Segundo a doutrina e a jurisprudência do STJ, o fato de terceiro só atua como excludente da responsabilidade quando tal fato for inevitável e imprevisível.

- O roubo do talonário de cheques durante o transporte por empresa contratada pelo banco não constituiu causa excludente da sua responsabilidade, pois se trata de caso fortuito interno.

- Se o banco envia talões de cheques para seus clientes, por intermédio de empresa terceirizada, deve assumir todos os riscos com tal atividade.

- O ônus da prova das excludentes da responsabilidade do fornecedor de serviços, previstas no art. $14, \S 3^{\circ}$, do CDC, é do fornecedor, por força do art. 12, § $3^{\circ}$, também do CDC. Recurso especial provido.

(RECURSO ESPECIAL Nº 685.662 - RJ, Rel. Min. Nancy Andrighi, $3^{\mathrm{a}}$ Turma, julgado em 10/11/2005). Disponível em: <https://ww2.stj.jus.br/processo/jsp/revista/abreDocumento.jsp?componente $=$ ITA\&sequencial $=593103 \&$ num_registro $=200401229836 \&-$ data=20051205\&formato=HTML $>$. Acesso em: 10 maio 2013.

17 RIZZARDO, Arnaldo. Condomínio edilício e incorporação imobiliária. 2. ed. Rio de Janeiro: Forense: 2012, p. 316.

18 "A hipoteca firmada entre a construtora e o agente financeiro, anterior ou posterior à celebração da promessa de compra e venda, não tem eficácia perante os adquirentes do imóvel".

19 FILHO, Sérgio Cavalieri. Programa de direito do consumidor. 2. ed. São Paulo: Atlas, 2010, p. 244. 
retardada, defeituosa), eis que figura no polo da relação contratual de forma oposta àquela determinada unidade. ${ }^{20}$

\section{A INCIDÊNCIA DO CÓDIGO DE DEFESA DO CONSUMIDOR}

Quando o incorporador/fornecedor vende e constrói unidades imobiliárias, assume a obrigação de dar coisa certa, sendo a essência do conceito de produto. Quando contrata a construção dessa unidade (por empreitada ou administração), assume uma obrigação de fazer, que se ajusta ao conceito de serviço.
Sendo tais obrigações assumidas com o destinatário final, formada está a relação de consumo e, como consequência, a incidência do Código de Defesa do Consumidor ${ }^{21}$ de forma impositiva, eis que se trata de normas de ordem pública. ${ }^{22}$

Havendo contratos celebrados por construtor que exerce habitual e profissionalmente a venda de imóveis, caracterizada está a relação de consumo, mesmo que o CDC não discipline contrato algum de forma específica, pois é aplicado a todos os tipos contratuais que gerem relação de consumo. ${ }^{23}$

Podemos observar, então, que a responsabilidade do incorporador

20 FILHO, Sérgio Cavalieri. Programa de direito do consumidor. 2. ed. São Paulo: Atlas, 2010, p. 244-245.

\section{1 “DIREITO CIVIL. CONTRATO DE INCORPORAÇÃO. CÓDIGO DE DEFESA DO CONSUMIDOR. APLICABILIDADE. RESTITUIÇÃO DE PARCELAS PAGAS. SÚMULA N.7/STJ.}

1. Em que pese o contrato de incorporação ser regido pela Lei n. 4.591/64, admite-se, outrossim, a incidência do Código de Defesa do Consumidor, devendo ser observados os princípios gerais do direito que buscam a justiça contratual, a equivalência das prestações e a boa-fé objetiva e vedam o locupletamento ilícito.

2. Aplica-se a Súmula n. 7 do STJ na hipótese em que a tese versada no recurso especial reclama a análise dos elementos fáticos produzidos ao longo da demanda.

3. Recurso especial não conhecido.

(REsp 747768 / PR RECURSO ESPECIAL 2005/0074645-6. Rel. Min. João Otávio de Noronha, $4^{\text {a }}$ Turma, julgado em 16/10/2009). Disponível em: <http://www.stj.jus. br/SCON/jurisprudencia/doc.jsp?livre=incorpora\%E7\%E3o+e+incid\%EAncia+do+CDC\&\&b=ACOR\&p=true\&t=JURIDICO\&l=10\&i=3>. Acesso em: 17 jul. 2013.

22 FILHO, Sérgio Cavalieri. Programa de direito do consumidor. 2. ed. São Paulo: Atlas, 2010, p. 245.

23 FILHO, Sérgio Cavalieri. Programa de direito do consumidor. 2. ed. São Paulo: Atlas, 2010, p. 245. 
decorre, além do contrato, da própria lei. Ele assume a obrigação de fazer, constituindo o seu último ato a entrega da unidade ou unidades. Assim, aquele que contrata a incorporação tem o dever de guardar a fidelidade ao prometido, sendo vedada a fuga unilateral dos termos acordados. Todavia, em não constatada a relação de consumo, mesmo em se tratando de construção, não incide o Código de Defesa do Consumidor. ${ }^{24}$ Os direitos refletidos no Código de Defesa do Consumidor não excluem os demais, de acordo com o que dispõe o artigo $7^{\mathrm{o}}$ da referida norma. ${ }^{25}$

\subsection{A incidência do Código de Defesa do Consumidor quanto à segurança da obra}

A responsabilidade, assim como no Código Civil em seu artigo 618, é objetiva. E no Código de Defesa do Consumidor é também para todo e qualquer acidente de consumo. Todavia, o fundamento é o defeito do produto ou do serviço, não sendo necessária a prova da culpa, como na legislação civil. ${ }^{26}$ Garantia de idoneidade legitimamente esperada. ${ }^{27}$

Os defeitos de construção (via de regra: concepção, projeto, cálculo,

24 CIVIL E PROCESSUAL. AGRAVO NO AGRAVO DE INSTRUMENTO. RECURSO ESPECIAL. AÇÃO DE RESTITUIÇÃO. CONTRATO DE EDIFICAÇÃO POR CONDOMÍNIO. CDC. INAPLICABILIDADE. INCIDÊNCIA DA LEI N. 4.591/64.

- Na hipótese de contrato em que as partes ajustaram a construção conjunta de um edifício de apartamentos, a cada qual destinadas respectivas unidades autônomas, não se caracteriza, na espécie, relação de consumo, regendo-se os direitos e as obrigações pela Lei n. 4.591/64.

- Agravo não provido.

(AgRg no Ag 1307222 / SP AGRAVO REGIMENTAL NO AGRAVO DE INSTRUMENTO 2010/0081575-0, Rel ${ }^{\mathrm{a}}$. Min ${ }^{\mathrm{a}}$. Nancy Andrighi, $3^{\mathrm{a}}$ Turma, julgado em 04/08/2011). Disponível em: http://www.stj.jus.br/SCON/jurisprudencia/doc.jsp?livre $=$ condom $\%$ EDnio $+\mathrm{e}+\mathrm{c} \% \mathrm{~F} 3$ digo + de + defesa + do + consumidor $\& \mathrm{~b}=\mathrm{ACOR} \& \mathrm{p}=$ true $\& \mathrm{t}$ $=\& \mathrm{l}=10 \& \mathrm{i}=9$. Acesso em: 12 jul. 2013.

25 MERELLES, Hely Lopes. Direito de construir. 10. ed. São Paulo: Malheiros, 2011, p. 295.

26 FILHO, Sérgio Cavalieri. Programa de responsabilidade civil. 2. ed. São Paulo: Atlas, 2010, p. 248.

27 FILHO, Sérgio Cavalieri. Programa de direito do consumidor. 2. ed. São Paulo: Atlas, 2010, p. 248. 
construção, fundação, concreta etc.) comprometem a estrutura da obra. E para a responsabilização é irrelevante o conhecimento do construtor acerca da existência do defeito, ou se era previsível ou evitável, pois o CDC, para os acidentes de consumo, o tem como presumido, eis que ao fornecedor cabe a prova da inexistência do defeito. Devemos atentar, também, para o fato de que os dirigentes da empresa podem ser responsabilizados, quando o juiz entender pela desconsideração da personalidade jurídica, de acordo com a norma protetiva dos consumidores.

\subsection{A incidência do Código de Defesa do Consumidor quanto à qualidade da obra}

Segundo Sérgio Cavalieri Filho, o foco principal de litígio entre construtores e consumidores é no tocante aos vícios de qualidade, que se verifica nos materiais de baixa qualidade e na má técnica utilizados na obra. Assim, em um primeiro momento, o empreendimento está aparentemente perfeito, acabado; já em um segundo momento, começam a aparecer as infiltrações, rachaduras, vazamentos, defeitos nas instalações hidráulicas e elétricas. ${ }^{28}$

Em conformidade com os artigos 18 e 20 do Código de Defesa do Consumidor, o fato gerador da responsabilidade é o vício do produto ou do serviço. Quanto ao vício, o defeito é menos grave e, embora não comprometa a segurança da obra, afeta a sua utilidade e reduz o valor. Assim, a responsabilidade pelo vício do produto ou do serviço decorre da falta de conformidade ou qualidade da coisa ou do serviço, em relação a sua perspectiva de durabilidade e utilidade. Já na responsabilidade pelo defeito na obra, por sua gravidade, objetivase a proteção da integridade pessoal do consumidor e dos seus bens; e na responsabilidade pelo vício, protegese a equivalência entre a prestação e a contraprestação. ${ }^{29}$

Não há prazos estabelecidos pelo CDC sobre os vícios de construção e seu momento, tal e qual como acontece no Código Civil (artigos 610 e 618). Todavia, há determinação que a durabilidade, a qualidade e a utilidade do produto ou do serviço devem corresponder às expectativas do consumidor, e criadas pelo fornecedor.

28 FILHO, Sérgio Cavalieri. Programa de direito do consumidor. 2a. ed. São Paulo: Atlas, 2010, p. 251.

29 FILHO, Sérgio Cavalieri. Programa de direito do consumidor. 2a. ed. São Paulo: Atlas, 2010, p. 251. 
Assim, deve guardar relação com o prazo normal e razoável de durabilidade do produto ou do serviço. No caso de a manifestação do defeito vir a ocorrer dentro desse período e não for decorrente do mau uso ou desgaste normal do tempo, o fornecedor deve responder. Portanto, a regra é a de que o produto ou o serviço deve guardar compatibilidade com a sua expectativa de durabilidade. ${ }^{30}$

\section{A RESPONSABILIDADE DO EMPREITEIRO E DO CONSTRUTOR}

É contratual ou extracontratual. Contratual quando decorre da inexecução da obra e suas obrigações. Violando o contrato ao não ser executada a obra nos seus termos ou de maneira defeituosa, verifica-se o inadimplemento do contrato, surgindo a responsabilidade civil, como as perdas e os danos previstos nos artigos 389 e 402 do Código Civil. Quanto aos lucros cessantes, podem ser incluídos, tais como a valorização do prédio; o resultado do negócio que nele seria explorado; os aluguéis que renderia e o que mais a construção pudesse render ao dono. Já a exoneração da responsabilidade contratual pode se dar verificado o caso fortuito ou força maior. Deve ser analisado o contrato. $^{31}$

Já a responsabilidade extracontratual é de ordem pública, referindo-se à perfeição, solidez, segurança da obra e também responsabilidade pelos danos em relação aos vizinhos e a terceiros. Incluem-se, ainda, sanções civis penais, tais como as previstas no Código de Ética que regula as profissões de engenheiro, arquiteto e agrônomo (Lei 5.194/66 - Código de Ética), o crime de desabamento ou desmoronamento previsto pelo artigo 256 do Código Penal e a Lei das Contravenções Penais. ${ }^{32}$

\subsection{O Código Civil e a responsabilidade pela perfeição da obra}

A perfeição da obra é responsabilidade presumida, não necessita constar em contrato, seja obra particular

30 FILHO, Sérgio Cavalieri. Programa de direito do consumidor. 2. ed. São Paulo: Atlas, 2010, p. 252.

31 GONÇALVES, Carlos Roberto. Responsabilidade civil. 14. ed. São Paulo: Saraiva, 2012, p. 382.

32 GONÇALVES, Carlos Roberto. Responsabilidade civil. 14. ed. São Paulo: Saraiva, 2012, p. 382. 
ou pública, pelo engenheiro, pelo agrônomo ou pelo arquiteto. Trata-se a construção civil, modernamente, como processo técnico de alta especialização. 33

Os artigos 615 e 616 do Código Civil confirmam a exigência da referida perfeição quando, respectivamente, autorizam a sua rejeição, por quem a encomendou, quando defeituosa, ou optam pelo abatimento do preço. Ainda, o material e a técnica aplicados não podem ser inadequados e insuficientes. De tal sorte que o contrato de construção envolve a obrigação de resultado, o que resulta em uma obra pronta e acabada, apta à utilização para os fins destinados. ${ }^{34}$

O construtor é responsável, pelo prazo de cinco anos, se o defeito aparecer dentro do prazo da garantia (art. 618 do Código Civil), sendo a responsabilidade objetiva. Contudo, após o prazo de cinco anos, mas observado prazo de duração razoável quanto à expectativa de durabilidade, a prova da culpa é indispensável. ${ }^{35}$

\subsection{A solidariedade entre incorporador e construtor}

Como vimos anteriormente, o incorporador, segundo os ditames da lei, é o que se chama de chave do empreendimento, vinculado de forma permanente. O incorporador, sendo aquele que compromissa ou efetiva a venda de frações de terrenos com o objetivo de vincular unidades autônomas, é tão responsável quanto o construtor e o proprietário do terreno. Assim, e de forma solidária, todos respondem pela inexecução do contrato, conforme textos legais. ${ }^{36}$ Tanto o Superior Tribunal de Justiça como

33 MEIRELLES, Hely Lopes. Direito de construir. 10. ed. São Paulo: Malheiros, 2011, p. 297.

34 MEIRELLES, Hely Lopes. Direito de construir. São Paulo: Malheiros, 2011, p. 297-298.

35 MEIRELLES, Hely Lopes. Direito de construir. São Paulo: Malheiros, 2011, p. 298. 36 FILHO, Sérgio Cavalieri. Programa de direito do consumidor. 2. ed. São Paulo: Atlas, 2010, p. 250. 
o Tribunal de Justiça ${ }^{37}$ perfilham do

mesmo entendimento. ${ }^{38}$

37 Ementa: APELAÇÃO CÍVEL. AÇÃO INDENIZATÓRIA. VÍCIOS CONSTRUTIVOS. RESPONSABILIDADE DO INCORPORADOR E CONSTRUTOR. AGRAVO RETIDO. Do agravo retido interposto pela ré Kaplan Incorporações (fls. 330-343) 1. Em se tratando de contrato decorrente das relações de consumo, aplica-se a teoria da aparência, de sorte que perante o consumidor é a demandada quem participou do referido pacto, razão pela qual é parte legítima para figurar no polo passivo da presente demanda, a teor do que estabelece o art. $3^{\circ}$, caput, do CDC. 2. A demandada Kaplan enquadra-se no conceito de incorporador previsto no parágrafo único do art. 29 da Lei 4.591 de 1964, regramento que também estabelece a solidariedade passiva entre os incorporadores. Do agravo retido interposto pela ré R\&O (fls. 346-349) 3. A jurisprudência pacífica tem reconhecido a legitimidade ativa do condomínio para estar em juízo, ainda que não registrada a respectiva convenção, pois evidente a universalidade de direitos a ser protegida nesta hipótese em prol dos condôminos. Mérito do recurso em exame 4. A parte demandada na condição de instituição prestadora de serviços se sujeita a aplicação das regras atinentes à lei consumerista, de acordo com disposto em seu art. $3^{\circ}$, $\S 2^{\circ}$. 5. Respondem solidariamente pelos defeitos evidenciados o construtor, causador direito do dano, que deve garantir a solidez e segurança da obra, bem como a incolumidade coletiva; e o incorporador, contratante da execução da obra. 6. O incorporador, ao celebrar o pacto de construção da obra, simplesmente se faz substituir na execução de uma tarefa, respondendo juntamente com o substituto pelos danos decorrentes de eventual falta contratual. 7. Desimporta para o deslinde da controvérsia se houve a aprovação pelo poder público do projeto arquitetônico e a expedição da carta de "habite-se, porquanto este se restringe a fiscalizar aspectos formais da construção. 8. Quanto à existência de vícios construtivos e irregularidades de acabamento, a prova pericial é esclarecedora. A perita nomeada pelo juízo destacou em seu laudo os diversos defeitos estruturais e relacionados ao acabamento, que são visíveis nas fotografias anexadas ao laudo pericial. 9. Diante da quase ausência de dados para se aquilatar o montante indenizatório devido, tenho que a liquidação de sentença por arbitramento deverá se ater aos defeitos constados no laudo pericial. Negado provimento aos agravos retidos e dado parcial provimento aos apelos. (Apelação Cível No 70031217102, Quinta Câmara Cível, Tribunal de Justiça do RS, Relator: Jorge Luiz Lopes do Canto, Julgado em 14/10/2009). Disponível em: <http://www.tjrs.jus.br/busca/?q=construtor+e+incorporador $+\mathrm{e}+$ solidariedade $\& \mathrm{tb}=$ jurisnova\&pesq $=$ ementario \&partialfields $=$ tribunal $\% 3 \mathrm{~A}-$ Tribunal\%2520de\%2520Justi\%25C3\%25A7a\%2520do\%2520RS.\%28TipoDecisao\%3Aac\%25C3\%25B3rd\%25C3\%25A3o|TipoDecisao\%3Amonocr\%25C3\%25A1 tica|TipoDecisao\%3Anull\%29\&requiredfields=\&as_q=>. Acesso em: 15 jul. 2013.

38 RECURSO ESPECIAL. INCORPORAÇÃO IMOBILIÁRIA. CONSTRUÇÃO DE EDIFÍCIO. VÍCIOS E DEFEITOS SURGIDOS APÓS A ENTREGA DAS UNIDADES AUTÔNOMAS AOS ADQUIRENTES. RESPONSABILIDADE SOLIDÁRIA DO INCORPORADOR E DO CONSTRUTOR. RECURSO PARCIALMENTE CONHECIDO E, NESSA PARTE, DESPROVIDO. 


\section{ALGUNS TIPOS DE INDENIZAÇÃO EM CONTRATOS DE PROMESSA DE COMPRA E VENDA}

Nas ações de rescisão contratual por atraso na entrega da obra, diversos são os pedidos pela parte lesada. Assim, importante ao presente estudo trazermos algumas decisões que tratam deferir condenações e entender pela nulidade de determinadas cláusulas.

\subsection{Atraso na entrega e prazo de tolerância}

Nesse caso, o prazo de tolerância estabelecido em cento e oitenta dias,

1. O incorporador, como impulsionador do empreendimento imobiliário em condomínio, atrai para si a responsabilidade pelos danos que possam resultar da inexecução ou da má execução do contrato de incorporação, incluindo-se aí os danos advindos de construção defeituosa.

2. A Lei n. 4.591/64 estabelece, em seu art. 31, que a "iniciativa e a responsabilidade das incorporações imobiliárias caberão ao incorporador”. Acerca do envolvimento da responsabilidade do incorporador pela construção, dispõe que "nenhuma incorporação poderá ser proposta à venda sem a indicação expressa do incorporador, devendo também seu nome permanecer indicado ostensivamente no local da construção", acrescentando, ainda, que "toda e qualquer incorporação, independentemente da forma por que seja constituída, terá um ou mais incorporadores solidariamente responsáveis” (art. 31, $\S \S 2^{\circ}$ e $\left.3^{\circ}\right)$.

3. Portanto, é o incorporador o principal garantidor do empreendimento no seu todo, solidariamente responsável com outros envolvidos nas diversas etapas da incorporação. Essa solidariedade decorre tanto da natureza da relação jurídica estabelecida entre o incorporador e o adquirente de unidades autônomas quanto de previsão legal, já que a solidariedade não pode ser presumida (CC/2002, caput do art. 942; CDC, art. 25, § $1^{\text {o}}$; Lei 4.591/64, arts. 31 e 43).

4. Mesmo quando o incorporador não é o executor direto da construção do empreendimento imobiliário, mas contrata construtor, fica, juntamente com este, responsável pela solidez e segurança da edificação (CC/2002, art. 618). Trata-se de obrigação de garantia assumida solidariamente com o construtor.

5. Recurso especial parcialmente conhecido e, nessa parte, desprovido.

(REsp 884367 / DFRECURSO ESPECIAL 2006/0196037-6, Rel Min. Raul Araújo, $4{ }^{\mathrm{a}}$ Turma, julgado em 06/03/2012). Disponível em: <http://www.stj.jus.br/SCON/jurisprudencia/doc.jsp?livre=incorpora\%E7\%E3o+e+cdc\&\&b=ACOR\&p=true\&t=\&l=10 \&i=4>. Acesso em: 11 jul. 2013. 
para atraso na entrega da obra, não foi entendido como abusivo, eis que considerada a complexidade para tais empreendimentos. ${ }^{39}$ Todavia, em sendo extrapolado o referido prazo, cabí- veis indenizações, nesse caso, por danos morais. ${ }^{40}$. Quanto às indenizações em decorrência do atraso da entrega da obra, exploraremos tal questão de forma mais detalhada, adiante.

39 Ementa: APELAÇÃO CÍVEL. PROMESSA DE COMPRA E VENDA. RESCISÃO CONTRATUAL. INDENIZAÇÃO. DANO MATERIAL. DANO MORAL. ATRASO NA ENTREGA DA OBRA. ABUSIVIDADE DA CLÁUSULA. O Termo de compromisso firmado pela construtora com o Ministério Público não retira o direito da parte autora de discutir o atraso na conclusão da obra, pois o compromisso assumido perante o Ministério Público não altera o contrato e representa apenas o reconhecimento do atraso e uma forma de tentar minorar os prejuízos dos consumidores, de um modo ou outro prejudicados pelo atraso verificado. A previsão contratual da tolerância de 180 dias na entrega da obra não se afigura abusiva. Na verdade é uma cláusula padrão nos contratos como o da espécie, em que se trata de empreendimento complexo e sujeito a situações involuntárias das mais variadas, ditas de força maior, que podem levar ao atraso na entrega de unidades edilícias. $\mathrm{O}$ atraso na entrega de obra do empreendimento gera dano moral passível de indenização, uma vez que a expectativa dos adquirentes foi frustrada. Da mesma maneira, o não cumprimento do prazo de conclusão autoriza o ressarcimento de valores despendidos com aluguel. NEGARAM PROVIMENTO À APELAÇÃO E DERAM PROVIMENTO AO RECURSO ADESIVO. UNÂNIME. (Apelação Cível No 70053480794, Vigésima Câmara Cível, Tribunal de Justiça do RS, Relator: Walda Maria Melo Pierro, Julgado em 10/07/2013). Disponível em: <http://www.tjrs. jus.br/busca/?q=atraso+e+obra+e+prazo+de+toler\%E2ncia\&tb=jurisnova\&pesq=ementario\&partialfields $=$ tribunal $\% 3$ ATribunal $\% 2520 \mathrm{de} \% 2520 \mathrm{Justi} \% 25 \mathrm{C} 3 \% 25 \mathrm{~A} 7 \mathrm{a} \%$ 2520do\%2520RS.\%28TipoDecisao\%3Aac\%25C3\%25B3rd\%25C3\%25A3o\%7CTipoDecisao\%3Amonocr\%25C3\%25A1tica\%7CTipoDecisao\%3Anull\%29\&requiredfields $=\&$ as_q $=>$. Acesso em: 15 jul. 2013.

40 Ementa: AÇÃO INDENIZATÓRIA. PROMESSA DE COMPRA E VENDA. ATRASO NA ENTREGA DO IMÓVEL. DANOS MORAIS. 1. A prova dos autos revelou que a construtora atrasou a entrega da obra por mais de 02 anos, portanto, inadimpliu o disposto no item "e" da promessa de compra e venda, que previa a entrega para agosto de 2010, bem como o prazo de tolerância de 180 dias, previsto na cláusula 5.1.1 do referido contrato. 2. Descabe, outrossim, justificar o atraso em razão da escassez de mão de obra, o que não caracteriza caso fortuito ou força maior. Trata-se dos riscos inerentes ao setor da economia da construção civil, e, portanto, hipótese de responsabilidade objetiva da ré. 3. Cabível reconhecer a existência de danos morais, pois a parte autora se deparou com diversos problemas que superaram a noção do mero aborrecimento do dia a dia, ou do mero descumprimento contratual. 4 . Danos materiais não foram comprovados. 5. Mantida a distribuição dos ônus sucumbenciais. 6. Sentença confirmada. APELAÇÕES DESPROVIDAS. (Apelação Cível N 70054244405, Décima Sétima Câmara Cível, Tribunal de Justiça do RS, Relator: 


\subsection{Comissão de corretagem}

Outro aspecto relevante e que provoca discussão no meio forense é em relação à possibilidade, ou não, da devolução dos valores pagos a título de comissão de corretagem.

Adiantando o nosso posicionamento, entendemos que tal verba deve, sim, fazer parte do montante da condenação, inclusive, para prestigiar o princípio da reparação integral, que será analisado mais a frente.

Todavia, queremos deixar claro que não estamos de forma alguma des- considerando o trabalho do profissional que intermediou e efetuou a venda. Inclusive, tem de receber a quantia que é sua por direito. Mas, nos casos de rescisão contratual por inexecução por parte do responsável, o risco não pode ser atribuído ao comprador ora consumidor, que é a parte mais fraca e, portanto, deve ser restituído na plenitude do que gastou.

A Justiça, como referido, ora entende pelo não ressarcimento ${ }^{41}$, ora entende pelo ressarcimento da comissão de corretagem ${ }^{42}$, como observamos nas decisões aqui trazidas.

Elaine Harzheim Macedo, Julgado em 04/07/2013). Disponível em: <http://www.tjrs. jus.br/busca/?q=atraso+e+obra+e+prazo+de+toler\%E2ncia\&tb=jurisnova\&pesq=ementario\&partialfields=tribunal $\% 3$ ATribunal $\% 2520 \mathrm{de} \% 2520 \mathrm{Justi} \% 25 \mathrm{C} 3 \% 25 \mathrm{~A} 7 \mathrm{a} \%$ 2520do\%2520RS.\%28TipoDecisao\%3Aac\%25C3\%25B3rd\%25C3\%25A30\%7CTipoDecisao\%3Amonocr\%25C3\%25A1tica\%7CTipoDecisao\%3Anull\%29\&requiredfields $=\&$ as_q $=>$. Acesso em: 15 jul. 2013.

41 Ementa: INDENIZATÓRIA. ATRASO NA ENTREGA DE OBRA POR CERCA DE UM ANO. FRUSTRAÇÃO DA JUSTA EXPECTATIVA DE CASAL RECÉM-CASADO. REPARAÇÃO DEVIDA. 1. DEVOLUÇÃO DE VALORES PERTINENTES A ENCARGOS MORATÓRIOS. Considerando que as obras não foram concluídas no prazo estipulado, inclusive após o período de tolerância de 180 dias, torna-se indevida a cobrança de multa e de juros moratórios pactuados sobre o valor do saldo a financiar, permitida, apenas, a correção monetária da respectiva quantia. AGRAVO RETIDO PREJUDICADO. 2. DESPESAS COM CONTRATAÇÃO DE ADVOGADO. As despesas havidas pela parte autora com a contratação de advogado não são passíveis de ressarcimento na forma de perdas e danos pela parte adversa, porquanto já se inserem na sucumbência prevista na condenação. 3. COMISSÃO DE CORRETAGEM. Tratando-se de honorários profissionais de intermediação, pagos ao corretor, entende-se que o respectivo valor não se integra o preço do imóvel, especialmente porque o provimento atingiria terceiro alheio às partes litigantes. Portanto, a verba indenizatória pretendida não é imputável às demandadas. 4. DANO MORAL. A compra da casa própria é um passo importante para qualquer família. No caso em particular, trata-se de família recém-formada, que foi alijada do uso da nova propriedade por cerca de um ano a contar da 
data prevista no contrato. Portanto, impõe-se majorar o valor da compensação. AGRAVO RETIDO PREJUDICADO. RECURSO DAS RÉS DESPROVIDO. RECURSO DOS AUTORES PROVIDO EM PARTE. VOTO DIVERGENTE. (Apelação Cível Nº 70054435185, Décima Sétima Câmara Cível, Tribunal de Justiça do RS, Relator: Elaine Harzheim Macedo, Julgado em 20/06/2013). Disponível em: <http://www.tjrs.jus. $\mathrm{br} /$ busca/?q=atraso+e+obra+e+comiss $\% E 3 o \& t b=j u r i s n o v a \& p e s q=e m e n t a r i o \& p a r t i a l-$ fields $=$ tribunal $\% 3$ ATribunal $\% 2520 \mathrm{de} \% 2520 \mathrm{Justi} \% 25 \mathrm{C} 3 \% 25 \mathrm{~A} 7 \mathrm{a} \% 2520 \mathrm{do} \% 2520 \mathrm{R}-$ S.\%28TipoDecisao\%3Aac\%25C3\%25B3rd\%25C3\%25A3o\%7CTipoDecisao\%3Amonocr\%25C3\%25A1tica\%7CTipoDecisao\%3Anull\%29\&requiredfields=\&as_q=>. Acesso em: 15 jul. 2013.

42 Ementa: APELOS CÍVEIS. PROMESSA DE COMPRA E VENDA. RESCISÃO CONTRATUAL C/C INDENIZAÇÃO POR DANOS MATERIAIS E MORAIS. DEVOLUÇÃO DOS VALORES PAGOS PELA AQUISIÇÃO DO IMÓVEL, VALORES DESPENDIDOS COM ALUGUEL NO PERÍODO DO ATRASO NA OBRA, BEM COMO DEVOLUÇÃO DE COMISSÃO DE CORRETAGEM. DANO MORAL NÃO CONFIGURADO. IMPROCEDENTE O PEDIDO DE DEVOLUÇÃO DE VALORES GASTOS COM A DESOCUPAÇÃO DO IMÓVEL ALUGADO. AFASTADA MULTA DE 2\% SOBRE O VALOR ATUALIZADO DO IMÓVEL. ÔNUS SUCUMBENCIAIS MANTIDOS. 1. Demonstrado pelo conjunto fático-probatório dos autos que a parte autora não recebeu o imóvel adquirido no prazo de entrega, nem, inclusive, nos 180 dias de prorrogação previstos no contrato, cabível a rescisão contratual, diante da culpa exclusiva da ré. 2. Condenada a demandada à devolução dos valores pagos pelo comprador, voltando as partes ao status quo, bem como ao pagamento dos valores a título de locação do imóvel onde residiu a parte autora após a não entrega do bem prometido, conforme valores apontados pela sentença. Devendo ainda arcar com o ressarcimento dos valores despendidos a título de comissão de corretagem, devido a culpa exclusiva do demando pela rescisão do contrato. 3. O descumprimento de cláusula contratual não gera, por si só, indenização por danos morais. Trata-se de contrato de promessa de compra e venda de imóvel ainda na planta, assumindo o adquirente os riscos próprios do negócio. Dano moral não configurado. 4. Já morando o autor de aluguel, descabida a pretensão de valores despendidos com a desocupação do imóvel, tendo em vista que ainda que não houvesse atraso na obra, o demandante arcaria de qualquer maneira com tal despesa. 5 . Não havendo previsão no contrato avençado e não se aplicando as penalidades previstas no TAC ajustado entre a ré e o MP/SP, afasto a aplicação de multa de $2 \%$ sobre o valor atualizado do imóvel. APELOS PARCIALMENTE PROVIDOS. (Apelação Cível No 70053361762, Décima Sétima Câmara Cível, Tribunal de Justiça do RS, Relator: Gelson Rolim Stocker, Julgado em 06/06/2013). Disponível em: <http://www.tjrs.jus. $\mathrm{br} /$ busca/?q=atraso $+\mathrm{e}+$ obra $+\mathrm{e}+$ comiss $\%$ E3o\&tb=jurisnova\&pesq=ementario\&partialfields $=$ tribunal $\% 3$ ATribunal $\% 2520 \mathrm{de} \% 2520 \mathrm{Justi} \% 25 \mathrm{C} 3 \% 25 \mathrm{~A} 7 \mathrm{a} \% 2520 \mathrm{do} \% 2520 \mathrm{R}-$ S.\%28TipoDecisao\%3Aac\%25C3\%25B3rd\%25C3\%25A3o\%7CTipoDecisao\%3Amonocr\%25C3\%25A1tica\%7CTipoDecisao\%3Anull\%29\&requiredfields=\&as_q=>. Acesso em: 15 jul. 2013. 


\subsection{Danos emergentes, lucros cessantes e perdas e danos}

A título de danos materiais, as demandas indenizatórias têm sido procedentes, também, quanto aos danos emergentes, lucros cessantes e perdas e danos $^{43}$, ressalvado, contudo, que deve ser feita a prova, pelo autor da ação, da existência dos lucros cessantes e das perdas e danos. Todavia, alguns julgados entendem que tais danos são presumidos ${ }^{44}$, em decorrência do inadimplemento do construtor e/ ou incorporador, quando do atraso da entrega da obra.

43 Ementa: APELAÇÃO CÍVEL. PROMESSA DE COMPRA E VENDA. AÇÃO DE EXECUÇÃO DE OBRIGAÇÃO DE FAZER COM PEDIDO DE INDENIZAÇÃO POR DANOS MORAIS, LUCROS CESSANTES E PERDAS E DANOS. CONTRATO DE PROMESSA DE COMPRA E VENDA DE IMÓVEL. ATRASO NA ENTREGA DA OBRA. RETARDO CONTRATUAL QUE, NO CASO, EMBORA DEMONSTRADO, NÃO AUTORIZA O ACOLHIMENTO DA PRETENSÃO INDENIZATÓRIA VEICULADA. DANOS MORAIS PELO ATRASO NA ENTREGA DA INFRAESTRUTURA DO IMÓVEL ADQUIRIDO. AUSÊNCIA DE PROVA DO DANO. INDEFERIMENTO. Resolvendo-se os contratos não cumpridos em perdas e danos, em cujo conceito legal se inserem apenas os efetivos prejuízos materiais e os lucros cessantes, os danos morais, de índole eminentemente extrapatrimonial, não se constitui, em regra, parcela indenizável pela inexecução contratual. Ainda assim, o atraso na entrega do imóvel, embora possa ter acarretado desconforto ao promitente comprador e alterações em seu cotidiano, por certo não trouxe maiores aborrecimentos do que aqueles a que todos estão sujeitos nas relações interpessoais inerentes à vida em sociedade. LUCROS CESSANTES. INDEFERIMENTO. AUSÊNCIA DE PROVA DE QUE O IMÓVEL SERIA UTILIZADO PARA AUFERIR LUCRO. DANOS EMERGENTES. RESSARCIMENTO POR ALUGUÉIS. INDEFERIMENTO. AUSÊNCIA DE PROVA DE GASTOS A TAL TÍTULO. RECURSO EM PARTE PROVIDO. UNÂNIME. (Apelação Cível No 70054121579, Décima Oitava Câmara Cível, Tribunal de Justiça do RS, Relator: Pedro Celso Dal Pra, Julgado em 25/04/2013). Disponível em: <http://www. tjrs.jus.br/busca/?q=atraso+e+obra+e+danos+emergentes\&tb=jurisnova\&pesq=ementario\&partialfields $=$ tribunal $\% 3$ ATribunal $\% 2520 \mathrm{de} \% 2520 \mathrm{Justi} \% 25 \mathrm{C} 3 \% 25 \mathrm{~A} 7 \mathrm{a} \%$ 2520do\%2520RS.\%28TipoDecisao\%3Aac\%25C3\%25B3rd\%25C3\%25A3o|TipoDecisao $\% 3$ Amonocr $\% 25 \mathrm{C} 3 \% 25 \mathrm{~A} 1$ tica|TipoDecisao $\% 3$ Anull $\% 29 \&$ requiredfields $=\&$ as q=>. Acesso em: 15 jul. 2013.

44 AGRAVO REGIMENTAL - COMPRA E VENDA. IMÓVEL. ATRASO NA ENTREGA - LUCROS CESSANTES - PRESUNÇAO - CABIMENTO - DECISÃO AGRAVADA MANTIDA - IMPROVIMENTO.

1. A jurisprudência desta Casa é pacífica no sentido de que, descumprido o prazo para entrega do imóvel objeto do compromisso de compra e venda, é cabível a condenação por lucros cessantes. Nesse caso, há presunção de prejuízo do promitente-comprador, cabendo ao vendedor, para se eximir do dever de indenizar, fazer prova de que a mora contratual não lhe é imputável. Precedentes. 


\subsection{Danos morais e aluguéis}

Pode-se pleitear, ainda, o ressarcimento dos gastos que o comprador teve de arcar, em razão do atraso da obra, a título de aluguel. Para tanto, é imprescindível a prova nesse sentido. ${ }^{45}$

\section{CONSTRUÇÃO POR ADMINISTRAÇÃO}

Esse tipo de contrato não se confunde com o contrato de empreitada.
Nessa modalidade, o construtor responsabiliza-se, tão somente, pela execução técnica do projeto, sendo o proprietário aquele quem custeia a obra, e somente reconhecido o preço ao final do empreendimento. O construtor, por sua vez, é remunerado através de um percentual sobre o custo da obra. ${ }^{46}$

Ainda, também pode ser convencionado que a aquisição dos materiais será pelo dono da obra ou a seu mando, pelo denominado construtor-administrador, este que atua como preposto ou mandatário. O Código Civil silencia sobre a contratação por administração,

2. O agravo não trouxe nenhum argumento novo capaz de modificar o decidido, que se mantém por seus próprios fundamentos.

3. Agravo Regimental improvido. (AgRg no RECURSO ESPECIAL No 1.202 .506 - RJ (2010/0123862-0), Relator Ministro Sidnei Beneti, Julgado em 07/02/2012.) Disponível em: <https://ww2.stj.jus.br/processo/jsp/revista/abreDocumento.jsp?componente= ITA\&sequencial $=1119515 \&$ num_registro $=201001238620 \&$ data $=20120224 \&$ formato $=$ HTML $>$. Acesso em: 15 jul. 2013.

45 Ementa: APELAÇÃO CÍVEL. PROMESSA DE COMPRA E VENDA. RESCISÃO CONTRATUAL. INDENIZAÇÃO. DANO MATERIAL. DANO MORAL. ATRASO NA ENTREGA DA OBRA. O atraso na entrega de obra de empreendimento gera dano moral passível de indenização, uma vez que a expectativa dos adquirentes foi frustrada. Da mesma maneira, o não cumprimento do prazo de conclusão autoriza o ressarcimento de valores despendidos com aluguel. NEGARAM PROVIMENTO À APELAÇÃO. UNÂNIME. (Apelação Cível No 70052650884, Vigésima Câmara Cível, Tribunal de Justiça do RS, Relator: Walda Maria Melo Pierro, Julgado em 26/06/2013)> Disponível em: <http://www.tjrs.jus.br/busca/?q=atraso+e+obra+e+alugu\%E9is\&tb=jurisnova\&pesq $=$ ementario\&partialfields $=$ tribunal $\% 3$ ATribunal $\% 2520 \mathrm{de} \% 2520 \mathrm{Jus}-$ ti\%25C3\%25A7a\%2520do\%2520RS.\%28TipoDecisao\%3Aac\%25C3\%25B3rd\%25C3\%25A3o\%7CTipoDecisao\%3Amonocr\%25C3\%25A1tica\%7CTipoDecisao\%3Anull\%29\&requiredfields=\&as_q=>. Acesso em: 15 jul. 2013.

46 GONÇALVES, Carlos Roberto. Responsabilidade civil. 14. ed. São Paulo: Saraiva, 2012, p. 381. 
sendo aplicadas, por sua vez, as regras atinentes ao contrato de empreitada, correndo os riscos por parte do dono da obra, a não ser nos casos de comprovada a existência de culpa do construtor. ${ }^{47}$

Vejamos a aplicação prática, pelo Tribunal de Justiça do Rio Grande do Sul, acerca da responsabilização dos proprietários de obras nesse tipo de modalidade de contratação. No caso em exame, foi afastada a responsabilidade de instituição financeira. A indenização, entre outras causas, tinha como causa de pedir o atraso da obra contratada, cuja responsabilidade foi atribuída aos proprietários que a custearam, e por ser efetuada na modalidade por administração. ${ }^{48}$

\section{DESISTÊNCIA DO CONTRATO PELOS COM- PRADORES E PERCENTUAL DE RETENÇÃO}

Questão que também merece importância é aquela que discute a desistência do contrato, pelo comprador, e o percentual que pode buscar, em relação ao que pagou, envolvendo a contratação.

Em que pese a regra geral, como já referido, ser pela impossibilidade da desistência, a jurisprudência tem acatado tal pedido, pelos adquirentes, e determinado percentual dos valores já pagos em favor do vendedor, para que sejam minimizados os prejuízos a

47 GONÇALVES, Carlos Roberto. Responsabilidade civil. 14. ed. São Paulo: Saraiva, 2012, p. 381.

48 Ementa: APELAÇÃO CÍVEL. AÇÃO DE RESOLUÇÃO DE CONTRATO C/C INDENIZAÇÃO POR DANOS MATERIAL E MORAL. CONTRATO PRÓ-CONSTRUÇÃO. CONDOMÍNIO A PREÇO DE CUSTO. CONSTRUÇÃO POR ADMINISTRAÇÃO. RESPONSABILIDADE DOS PROPRIETÁRIOS PELO CUSTEIO DA OBRA. LEI 4591/64. ATRASO NA ENTREGA DAS UNIDADES. FATO NÃO IMPUTÁVEL AO CONSTRUTOR. FINANCIAMENTO IMOBILIÁRIO. AUSENTE RESPONSABILIDADE DA INSTITUIÇÃO FINANCEIRA. PRELIMINAR. INVERSÃO DO ÔNUS DA PROVA. SUCUMBÊNCIA MODIFICADA. PROVIDAS ÀS APELAÇÕES. UNÂNIME. (Apelação Cível N 70046473757, Décima Oitava Câmara Cível, Tribunal de Justiça do RS, Relator: Nara Leonor Castro Garcia, Julgado em 21/06/2012). Disponível em: <http://www.tjrs.jus.br/busca/?q=atraso+e+obra+e+comiss $\%$ E3o \& tb=jurisnova\&pesq $=$ ementario \& partialfields $=$ tribunal $\% 3 \mathrm{ATribunal} \%$ 2520de\%2520Justi\%25C3\%25A7a\%2520do\%2520RS.\%28TipoDecisao\%3Aac\%25C3\%25B3rd\%25C3\%25A3o\%7CTipoDecisao\%3Amonocr\%25C3\%25A1tica\%7CTipoDecisao\%3Anull\%29\&requiredfields=\&as_q=>. Acesso em: 15 jul. 2013. 
serem suportados. ${ }^{49}$ Portanto, a cláusula de retenção, nos casos de desistência pura e simples do comprador, sem motivo relevante, parecer ser considerada válida, pela jurisprudência. ${ }^{50}$ Tanto é verdade que o Superior

49 Ementa: CONTRATO PARTICULAR DE PROMESSA DE COMPRA E VENDA. MODALIDADE DE 'TIME SHARING”. RESCISAO PELO COMPRADOR DE FORMA UNILATERAL. RECONHECIMENTO DA TOTAL AUSÊNCIA DE UTILIDADE DO CONTRATO PARA O COMPRADOR, CUJO PERIODO À DISPOSIÇÃO DA UNIDADE HABITACIONAL REPRESENTAVA IMPOSSIBILIDADE DE DESFRUTE DO EMPREENDIMENTO. RELAÇÃO NEGOCIAL QUE ESTÁ SUJEITA ÀS DISPOSIÇÕES DO CDC, SENDO ABUSIVA A CLÁUSULA QUE PREVE DECAIMENTO TOTAL PELO COMPRADOR EM CASO DE DESISTÊNCIA - ART-53 DO CDC. POSSIBILIDADE, CONTUDO, DE RETENÇÃO DE 10\% DO VALOR TOTAL DAS PRESTAÇÕES PAGAS - ART-924 DO CC. APELO PARCIALMENTE PROVIDO, PARA AUTORIZAR ESTA DEDUÇÃO DOS VALORES PAGOS PELA PARTE APELADA. (Apelação Cível No 599287083, Vigésima Câmara Cível, Tribunal de Justiça do RS, Relator: José Aquino Flôres de Camargo, Julgado em 15/06/1999). Disponível em: <http://www.tjrs. jus.br/busca/?q=empreendimento+e+desist\%EAncia+e+reten\%E7\%E3o\&tb=jurisnova\&pesq=ementario\&partialfields=tribunal\%3ATribunal\%2520de\%2520Justi\%25C3\%25A7a\%2520do\%2520RS.\%28TipoDecisao\%3Aac\%25C3\%25B3rd\%25C3\%25A3o\%7CTipoDecisao\%3Amonocr\%25C3\%25A1tica\%7CTipoDecisao\%3Anull\%29\&requiredfields=\&as_q=>. Acesso em: 15 jul. 2013.

50 Ementa: INCORPORAÇÃO IMOBILIÁRIA. PROMESSA DE COMPRA E VENDA. RESOLUÇÃO. INADIMPLEMENTO. CLÁUSULAS NULAS. Ainda que não conste do contrato data para o início das obras do edifício, mas havendo fixação do prazo para a conclusão da obra, não é razoável inferir que, não iniciadas aquelas dois anos antes do prazo previsto para a entrega, a construtora não o cumpriria. Hipótese em que os autores ingressaram em juízo apenas quatro meses após a contratação, prazo no qual, normalmente, a construtora está a vender número mínimo de unidades a viabilizar o início do empreendimento. Necessidade, no caso, de notificação da construtora para que constituída em mora, podendo os autores valer-se, também, do disposto no art. 1.092, segunda parte, do Código Civil revogado. Resolução por inadimplemento da construtora inviável. Não é nula a cláusula contratual que prevê a retenção, em caso de desistência dos promitentes-compradores, de valores para indenizar despesas feitas com a contratação. Excessivo, todavia, o percentual ajustado, que totaliza 22\%, razoável reduzi-lo para cerca de $6 \%$, e que corresponde justamente aos valores pagos pelos apelantes. Procedência parcial da demanda, tão somente para decretar a resilição do contrato ante a desistência dos promitentes-compradores, sem direito à restituição dos valores pagos, limitando a retenção de valores ao que já pago à promitente-vendedora, a título de indenização por despesas feitas pela construtora. RECURSO PARCIALMENTE PROVIDO. UNÂNIME. (Apelação Cível No 70001683762, Décima Oitava Câmara Cível, Tribunal de Justiça do RS, Relator: Pedro Luiz Pozza, Julgado em 30/06/2003). 
Tribunal de Justiça, inclusive, joga uma pá de cal na questão. ${ }^{51}$

Nesse último julgado, importante referir que foi autorizada a retenção em apenas 10\% (dez por cento), afastando a cláusula penal de $30 \%$, sem dúvida excessivamente onerosa e abusiva, na espécie.

Contudo, Arnaldo Rizzardo alerta que tal consideração em relação à desistência constitui precedente perigoso, quando se trata de incorporação.
As consequências podem ser sérias, eis que a desistência pode refletir diretamente na estrutura de todo um planejamento, que pode, segundo o mestre, inviabilizar o setor da construção. Ainda, aduz que terceiros adquirentes serão prejudicados, dado o agravamento dos encargos. Releva que as decisões que entendem pela possibilidade da desistência geram instabilidade, asseverando ainda que, no mínimo, a restituição deve ser

Disponível em: <http://www.tjrs.jus.br/busca/?q=incorpora\%E7\%E3o+e+prazo+pa$\mathrm{ra}+$ desist $\%$ EAncia\&tb=jurisnova\&pesq $=$ ementario\&partialfields $=$ tribunal $\% 3 \mathrm{ATribu}-$ nal\%2520de\%2520Justi\%25C3\%25A7a\%2520do\%2520RS.\%28TipoDecisao\%3Aac\%25C3\%25B3rd\%25C3\%25A3o\%7CTipoDecisao\%3Amonocr\%25C3\%25A1tica\%7CTipoDecisao\%3Anull\%29\&requiredfields=\&as_q=>. Acesso em: 15 jul. 2013.

51 “CIVIL E PROCESSUAL. COOPERATIVA HABITACIONAL. TERMO DE ADESÃO PARA COMPRA DE IMÓVEL. DESISTÊNCIA. AÇÃO PRETENDENDO O RESSARCIMENTO DAS IMPORTÂNCIAS PAGAS. RETENÇÃO SOBRE PARTE DAS PARCELAS DETERMINADA EM PERCENTUAL INFERIOR AO PREVISTO CONTRATUALMENTE. CLÁUSULA ABUSIVA. SITUAÇÃO PECULIAR. OBRA SEQUER INICIADA. DESPESAS ADMINISTRATIVAS IRRELEVANTES. CÓDIGO DE DEFESA DO CONSUMIDOR, ARTS. 51, II, 53 E 54. CÓDIGO CIVIL, ART. 924.

I. A C. $2^{\text {a }}$ Seção do STJ, em posição adotada por maioria, admite a possibilidade de resilição do compromisso de compra e venda por iniciativa do devedor, se este não mais reúne condições econômicas para suportar o pagamento das prestações avençadas com a empresa vendedora do imóvel (EREsp n. 59.870/SP, rel. Min. Barros Monteiro, DJU de 09.12.2002).

II. O desfazimento do contrato dá ao comprador o direito à restituição das parcelas pagas, porém não em sua integralidade.

III. Caso em que, em face das circunstâncias peculiares da causa, a retenção determinada pelo Tribunal a quo se fez em parâmetro razoável.

IV. Recurso especial não conhecido.

(REsp 403189 / DF RECURSO ESPECIAL 2002/0002585-1, Rel. Min. Aldir Passarinho Junior, $4^{\text {a }}$ Turma, julgado em 25/03/2003). Disponível em: <http://www.stj.jus.br/ SCON/jurisprudencia/doc.jsp?livre=obra+e+desist\%EAncia+e+reten\%E7\%E3o\&\&b $=A C O R \& p=$ true $\& \mathrm{t}=\& \mathrm{l}=10 \& \mathrm{i}=1>$. Acesso em: 15 jul. 2013. 
postergada para momento posterior, quando a venda da unidade conseguir ser refeita. ${ }^{52}$

\section{COBRANÇA DE JUROS DURANTE A CONSTRUÇÃO}

Tal tema é objeto de discussão, seja nos corredores forenses, seja pela doutrina; e há divisão de entendimentos, fato este que não pacifica a questão. Há posicionamento de que a cobrança de juros antes da entrega das chaves, do imóvel em construção, caracteriza cláusula abusiva. Inclusive, o item 14 da Portaria n. 03/2001, da Secretaria de Direitos Econômicos do Ministério da Justiça, foi considerado abusivo. ${ }^{53} \mathrm{~A}$ sustentação para tal abusividade é que a cobrança de juros antes da entrega das chaves acarreta cumprimento de obrigação, sem a devida contraprestação correspondente, eis que o consumidor, na data da assinatura do contrato, não recebe nada naquele momento; portanto, seria incabível pagar juros por algo não recebido. Ainda, outra justificativa é que os juros cobrados antecipadamente não integram o preço do imóvel e ainda causam enriquecimento sem causa para a outra parte. A unidade, por sua vez, tem o seu preço fixado em função do mercado, levando em consideração a oferta e a procura. Por último, o financiamento do imóvel é feito pelo próprio comprador, que adianta parte do preço, de tal sorte que não se fala em utilização do dinheiro da construtora emprestado ao adquirente, nem em juros moratórios, pois não existe atraso no cumprimento da obrigação. ${ }^{54}$

Por outro lado, há os que sustentam, com base no $\S 2^{\circ}$ do artigo $5^{\circ}$ da lei de n. 9514/97, esta que autoriza o financiador, em se tratando de vendas de imóveis na forma parcelada, cobrar juros compensatórios que se destinam a remunerar o capital emprestado. Alega-se, ainda, que o pagamento efetuado pelo comprador durante a construção representa $30 \%$ do custo do imóvel, motivo pelo qual o construtor teria de investir na obra recursos próprios, ou financiar. Por tais razões não haveria ilegalidade no procedimento de cobrança de juros durante a construção. Os juros, por assim dizer, são a remuneração de um

52 RIZZARDO, Arnaldo. Condomínio edilício e incorporação imobiliária. 2. ed. Rio de Janeiro: Forense, 2012, p. 285-286.

53 "Estabeleça, no contrato de compra e venda de imóvel, a incidência de juros antes da entrega das chaves”.

54 FILHO, Sérgio Cavalieri. Programa de responsabilidade civil. 2. ed. São Paulo: Atlas, 2010,p. 254-255. 
capital e são devidos no momento em que o dinheiro sai das mãos do proprietário e é entregue, por empréstimo, ao beneficiário. ${ }^{55}$

O Superior Tribunal de Justiça parece prestigiar a segunda corrente. A fundamentação do voto foi no sentido de afastar qualquer declaração de nulidade de cláusula contratual, conforme postularam os autores: o acórdão também considerou que "não tem pertinência a alegação dos autores de que os juros somente deveriam ter sido cobrados quando da entrega da unidade, avalizando a sentença: 'equivocam-se os autores, quando aduzem que só nasce o contrato de mútuo quando da entrega da unidade'. Não existe mútuo, mas pagamento, que, em regra, nos contratos de incorporação imobiliária, é feito na data da celebração, e não na da entrega da unidade". ${ }^{56}$

Sérgio Cavalieri Filho, ao comentar posição contrária ao julgamento acima trazido, em referência à decisão do então Des. Luiz Felipe Salomão, disse como a mais acertada, eis que declara nula cláusula que estipula juros durante a obra. ${ }^{57}$

55 FILHO, Sérgio Cavalieri. Programa de responsabilidade civil. 2. ed. São Paulo: Atlas, 2010, p. 255.

56 “Contrato de compra e venda de imóvel. Pagamento parcelado. Juros legais da data da assinatura do contrato.

1. Não é abusiva a cláusula do contrato de compra e venda de imóvel que considera acréscimo no valor das prestações, desde a data da celebração, como condição para o pagamento parcelado.

2. Recurso especial não conhecido. (Recurso Especial No 379.941 - SP (2001/0172439-

2), Rel. Min. Carlos Alberto Menezes de Direito, $3^{\mathrm{a}}$ Turma, julgado em 03/10/2002). Disponível em: <https://ww2.stj.jus.br/processo/jsp/revista/abreDocumento.jsp?compo nente $=$ ITA\&sequencial $=376329 \&$ num_registro $=200101724392 \&$ data $=20021202 \&$ for mato=HTML> . Acesso em: 11 jul. 2013.

57 Apelação Cível. Ação objetivando declaração de nulidade de cláusula contratual e repetição de indébito, em razão de financiamento de imóvel pela incorporadora. Cobrança de juros compensatórios antes da entrega das chaves ao consumidor. Rejeição das preliminares de ilegitimidade passiva e impossibilidade jurídica de revisão do contrato, na medida em que há pertinência subjetiva diante da aparência do contratante como representante da apelante, com expressa previsão legal a permitir o exame de sua revisão. Antes da conclusão e entrega do imóvel aos autores, não há que falar em remuneração de capital. Onerosidade excessiva para o consumidor. Os juros representam a remuneração do capital. Para sua incidência em caráter de retribuição, é necessário a contrapartida do tomador, pena de enriquecimento sem causa. Incabível, portanto, cobrança de juros compensatórios. Os juros aplicados têm tampouco natureza remuneratória, eis que inexistem qualquer inadimplemento. Abusividade da cláusula corretamente reconhecida 
O Tribunal de Justiça do Rio Grande do Sul, ao analisar casos análogos, parece seguir o entendimento do Superior Tribunal de Justiça, acer- ca da legalidade da cobrança de juros antes da entrega das chaves ${ }^{58}$ Todavia, ao apreciar a matéria, entendimento diverso foi aplicado ao caso. ${ }^{59}$

pela sentença. Precedentes jurisprudenciais. Devolução em dobro do indébito. Com aplicação do disposto no artigo 42, parágrafo único do CDC. Recurso Improvido.

(Apelação Cível nº 2005.001.50280, Rel. Des. Luis Felipe Salomão, 6ª Câmara Cível, julgado em 08/0/2006). Disponível em: <http://www1.tjrj.jus.br/gedcacheweb/ default.aspx?UZIP=1\&GEDID=00037D29323BDCDF1DC3647CAE73D38F4C6B2 3C402052932>. Acesso em: 11 jul. 2013.

58 Ementa: APELAÇÃO CÍVEL. PROMESSA DE COMPRA E VENDA. IMÓVEL EM FASE DE CONSTRUÇÃO. COBRANÇA DE JUROS COMPENSATÓRIOS ANTES DA ENTREGA DAS CHAVES - JUROS NO PÉ. LEGALIDADE. ENTENDIMENTO DO STJ. Estando o imóvel negociado em fase de construção, não se considera abusiva cláusula contratual que preveja a cobrança de juros compensatórios antes da entrega das chaves. Entendimento fixado no E. STJ por meio do REsp 670.117/PB. Logo, mostra-se legal a cláusula do instrumento particular de promessa de compra e venda de imóvel firmado entre as partes que previu a cobrança de juros simples de 1\% a partir da assinatura do contrato. Improcedência dos pedidos iniciais. RECURSO DA RÉ PROVIDO E RECURSO DOS AUTORES PREJUDICADO. UNÂNIME. (Apelação Cível No 70054935515, Décima Sétima Câmara Cível, Tribunal de Justiça do RS, Relator: Liege Puricelli Pires, Julgado em 04/07/2013). Disponível em: <http://www. tjrs.jus.br/busca/?q=juros+antes+da+entrega+das+chaves\&tb=jurisnova\&pesq=ementario\&partialfields $=$ tribunal $\% 3$ ATribunal $\% 2520 \mathrm{de} \% 2520 \mathrm{Justi} \% 25 \mathrm{C} 3 \% 25 \mathrm{~A} 7 \mathrm{a} \%$ 2520do\%2520RS.\%28TipoDecisao\%3Aac\%25C3\%25B3rd\%25C3\%25A3o|TipoDecisao $\% 3$ Amonocr $\% 25 \mathrm{C} 3 \% 25 \mathrm{~A} 1$ tica|TipoDecisao $\% 3$ Anull $\% 29 \&$ requiredfields $=\&$ as $\mathrm{q}=>$. Acesso em 11 jul. 2013.

59 Ementa: PROMESSA DE COMPRA E VENDA. AÇÃO INDENIZATÓRIA POR INADIMPLEMENTO CONTRATUAL. Pedido dos réus para afastamento da condenação ao pagamento de aluguéis não conhecido. Validade da cláusula que prevê a prorrogação da entrega das chaves do apartamento em 180 dias, pois redigida de acordo com o disposto no art. 54, §3 do CDC. O montante a ser devolvido à autora pelos réus deve se dar de forma simples, uma vez que não demonstrada má-fé por parte dos demandados. Os réus devem ressarcir à autora os valores por ela pagos a títulos de juros compensatórios e taxa condominial vencida até 10.05.2011, pois tais encargos incidiram antes da entrega das chaves do imóvel. Os honorários advocatícios, em face do acordo formulado pela autora e o condomínio para o pagamento de chamada extra e taxa condominial, devem ser pagos pelos demandados. Apelação da autora improvida e apelo dos réus conhecido em parte e, nesta, desprovido. (Apelação Cível No 70053684072 , Décima Nona Câmara Cível, Tribunal de Justiça do RS, Relator: Voltaire de Lima 


\section{A CLÁUSULA DE DECAIMENTO}

Em que pese a tentativa de imposição de cláusula que venha a prever a perda total das quantias pagas pelo consumidor caso o contrato venha a ser rescindido pelo inadimplemento daquele (cláusula de decaimento), tal cláusula é considerada inválida, cir- cunstância que vem a prestigiar o artigo 53 do Código de Defesa do Consumidor. ${ }^{60}$ Apenas admite-se a retenção de percentual pequeno do montante pago, a título de ressarcimento de despesas, buscando-se, dessa maneira, evitar-se o enriquecimento sem causa. Como se não bastasse, o Superior Tribunal de Justiça corrobora tal entendimento. ${ }^{61}$

Moraes, Julgado em 09/04/2013). Disponível em: <http://www.tjrs.jus.br/busca/?q=juros + antes + da + entrega + das + chaves $\&$ tb $=$ jurisnova\&pesq $=$ ementario\&partialfields $=$ tribunal\%3ATribunal\%2520de\%2520Justi\%25C3\%25A7a\%2520do\%2520RS.\%28TipoDecisao\%3Аac\%25C3\%25B3rd\%25C3\%25A3o|TipoDecisao\%3Amonocr\%25C3\%25A1tica|TipoDecisao\%3Anull\%29\&requiredfields=\&as_q=>. Acesso em 11 jul. 2013.

60 Art. 53. Nos contratos de compra e venda de móveis ou imóveis mediante pagamento em prestações, bem como nas alienações fiduciárias em garantia, consideram-se nulas de pleno direito as cláusulas que estabeleçam a perda total das prestações pagas em benefício do credor que, em razão do inadimplemento, pleitear a resolução do contrato e a retomada do produto alienado.

61 EMBARGOS DE DIVERGÊNCIA. DIREITO CIVIL. INCORPORAÇÃO IMOBILIÁRIA. IMÓVEL EM FASE DE CONSTRUÇÃO. COBRANÇA DE JUROS COMPENSATÓRIOS ANTES DA ENTREGA DAS CHAVES. LEGALIDADE.

1. Na incorporação imobiliária, o pagamento pela compra de um imóvel em fase de produção, a rigor, deve ser à vista. Nada obstante, pode o incorporador oferecer prazo ao adquirente para pagamento, mediante parcelamento do preço. Afigura-se, nessa hipótese, legítima a cobrança de juros compensatórios.

2. Por isso, não se considera abusiva cláusula contratual que preveja a cobrança de juros antes da entrega das chaves, que, ademais, confere maior transparência ao contrato e vem ao encontro do direito à informação do consumidor (art. $6^{\circ}$, III, do CDC), abrindo a possibilidade de correção de eventuais abusos.

3 No caso concreto, a exclusão dos juros compensatórios convencionados entre as partes, correspondentes às parcelas pagas antes da efetiva entrega das chaves, altera o equilíbrio financeiro da operação e a comutatividade da avença.

4. Precedentes: REsp n. 379.941/SP, Relator Ministro CARLOS ALBERTO MENEZES DIREITO, TERCEIRA TURMA, julgado em 3/10/2002, DJ 2/12/2002, p. 306, REsp n. 1.133.023/PE, REsp n. 662.822/DF, REsp n. 1.060.425/PE e REsp n. 738.988/ DF, todos relatados pelo Ministro ALDIR PASSARINHO JÚNIOR, REsp n. 681.724/ DF, relatado pelo Ministro PAULO FURTADO (Desembargador convocado do TJBA), e REsp n. 1.193.788/SP, relatado pelo Ministro MASSAMI UYEDA. 


\section{A CONSTRUÇÃO E O PRINCÍPIO DA REPARAÇÃO INTEGRAL}

Caracterizado como direito básico do consumidor, o direito à efetiva reparação consagra o princípio da reparação integral dos danos. Traduz-se, por assim dizer, no sentido de que todos os danos sofridos pelo consu- midor, todos os prejuízos devem ser reparados. Portanto, o Código de Defesa do Consumidor regula diferentemente do que ocorre com o artigo 944 parágrafo único do Código Civil, o qual possibilita a redução equitativa da indenização, considerando o grau de culpa do ofensor. Todavia e como regra, o CDC consagrou a responsabilidade objetiva (subjetiva, entretanto,

5. Embargos de divergência providos, para reformar o acórdão embargado e reconhecer a legalidade da cláusula do contrato de promessa de compra e venda de imóvel que previu a cobrança de juros compensatórios de $1 \%$ (um por cento) a partir da assinatura do contrato. (EREsp 670117 / PB EMBARGOS DE DIVERGÊNCIA EM RECURSO ESPECIAL 2010/0182236-6, Rel. Min. Sidnei Beneti, 2a Seção, julgado em 13/06/2012). Disponível em: <http://www.stj.jus.br/SCON/jurisprudencia/doc.jsp?livre=incorpora\%E7\%E3o+e+cdc\&\&b=ACOR\&p=true\&t=\&l=10\&i=2>. Acesso em 11 jul. 2013. CIVIL. PROMESSA DE COMPRA E VENDA. AÇÃO PRETENDENDO A RESCISÃO E RESTITUIÇÃO DAS IMPORTÂNCIAS PAGAS. INADIMPLÊNCIA DAAUTORA RECONHECIDA. POSSE DO IMÓVEL POR LONGO TEMPO. RETENÇÃO DE 50\% EM FAVOR DA VENDEDORA, COMO RESSARCIMENTO DE DESPESAS. CÓDIGO DE DEFESA DO CONSUMIDOR, ARTS. 51, II, 53 E 54. CÓDIGO CIVIL, ART. 924. JUROS MORATÓRIOS INDEVIDOS.I. A C. $2^{\text {a }}$ Seção do STJ, em posição adotada por maioria, admite a possibilidade de resilição do compromisso de compra e venda por iniciativa do devedor, se este não mais reúne condições econômicas para suportar o pagamento das prestações avençadas com a empresa vendedora do imóvel e, aqui, recaiu em inadimplência contratual (EREsp n. 59.870SP, rel. Min. Barros Monteiro, DJU de 09.12.2002). III. O desfazimento do contrato dá ao comprador o direito à restituição das parcelas pagas, porém não em sua integralidade, notadamente quando este recebeu as chaves e vem habitando o imóvel há vários anos, sob pena de se proporcionar enriquecimento sem causa do autor, cuja inadimplência no pagamento de parcela intermediária foi reconhecida nos autos. Percentual de retenção fixado em $50 \%$, em face da peculiaridade do caso. IV. Incabível a condenação em juros moratórios da ré, se além de haver ensejado motivo à rescisão, o autor ainda retém o imóvel. V. Recurso especial conhecido e parcialmente provido.

(Recurso Especial no 615.300 - MG (2003/0217150-4), Rel. Des. Aldir Passarinho Junior, $4^{a}$ Turma, julgado em 17/03/2005). Disponível em: <https://ww2.stj.jus.br/processo/jsp/revista/abreDocumento.jsp?componente=ATC\&sequencial=1521628\&num registro $=200302171504 \&$ data $=20050509 \&$ tipo $=5 \&$ formato $=$ HTML $>$. Acesso em 11 jul. 2013. 
apenas para os profissionais liberais), o que faz com que não se admita qualquer tipo de mitigação da responsabilidade ou do montante a título de condenação. ${ }^{62}$

Primordial é o conceito da reparação integral acima trazido. Ora, nos casos de rescisão contratual motivada pela inexecução do contrato pelo responsável, e em se tratando a discussão travada nos autos que envolva relação de consumo, a indenização e ressarcimento integral é medida impositiva. Caso tal princípio não seja observado, certamente, irá refletir em uma con- denação, quando em favor do vulnerável, que não consagrará o referido princípio. Mais ainda: acarretará em dupla punição ao consumidor: a um, porque o montante final não observará a efetiva reparação; a dois, porque, embora tratando de relação de consumo, o consumidor terá um desequilíbrio em face de pessoa jurídica, circunstância esta que ofende o Código de Defesa do Consumidor, eis que tal norma busca trazer o consumidor para uma relação igual com o fornecedor. Nesse sentido, a posição do Superior Tribunal de Justiça. ${ }^{63}$

62 MIRAGEM, Bruno. Curso de direito do consumidor. 3. ed. São Paulo: Revista dos Tribunais, 2012, p. 179-180.

63 EMBARGOS DE DIVERGÊNCIA EM RECURSO ESPECIAL. CONTRATO. COMPROMISSO DE COMPRA E VENDA DE IMÓVEL. RESOLUÇÃO POR CULPA DA CONSTRUTORA. RESTITUIÇÃO DA INTEGRALIDADE DAS PARCELAS PAGAS. NÃO CABIMENTO DA DEMONSTRAÇÃO DA DIVERGÊNCIA COM ACÓRDÃOS DA MESMA TURMA DO ACÓRDÃO EMBARGADO. INEXISTÊNCIA DE SIMILITUDE FÁTICA ENTRE OS ACÓRDÃOS CONFRONTADOS. DIVERGÊNCIA ULTRAPASSADA POR ENTENDIMENTO NO MESMO SENTIDO DA SEGUNDA SEÇÃO. INCIDÊNCIA DA SÚMULA Nº 168STJ. EMBARGOS DE DIVERGÊNCIA IMPROVIDOS.

1. Não caracteriza a divergência a invocação de julgados paradigmas da mesma Turma, ainda mais quando inexiste a similitude fática entre os acórdãos confrontados.

2. No caso, houve resolução do contrato de compromisso de compra e venda de imóvel, por culpa da incorporadora, que não realizou a entrega da unidade prometida. Por isso, está obrigada a devolver integralmente a quantia paga pelo comprador.

3. Embargos improvidos.

(EMBARGOS DE DIVERGÊNCIA EM RESP Nº 644.984 - RJ (2005/0162830-7), Relator Ministro Luis Felipe Salomão, $2^{\mathrm{a}}$ Turma, Julgado em 25/11/2009). Disponível em: $<$ https://ww2.stj.jus.br/processo/jsp/revista/abreDocumento.jsp?componente=ITA\&sequencial $=932409 \&$ num_registro $=200501628307 \&$ data $=20091218 \&$ formato $=$ HT ML.> Acesso em 15 jul. 2013. 


\section{CONSIDERAÇÕES FINAIS}

Observamos, com o presente trabalho, a importância dos contratos de incorporação. A responsabilidade é realmente forte, é fundamental, como deve ser, afinal, o direito à moradia, à propriedade. Portanto, aquele que se compromete a entregar a obra deve fazer de acordo e nos limites do contrato, no sentido de evitar as ações judicias que inundam os foros.

A incidência do Código de Defesa do Consumidor é pacífica nesse tipo de contratação e, como consequência, deve ser observada a norma protetiva a integralidade, sob pena de, além de se passar os custos e riscos do empreendimento aos consumidores, avalizar-se injustiças sem precedentes, quando da inexecução por parte do responsável. Os princípios da transparência, informação, boa-fé objetiva devem sempre pautar as contratações.

\section{REFERÊNCIAS}

BRASIL. Código Civil. Diário Oficial da União, Poder Executivo, Brasília, DF, 01 jan. 2002. Disponível em: <http://www.planalto.gov. br/ccivil_03/LEIS/2002/L10406. htm>. Acesso em: 16 maio 2013. . Código de Defesa do Consumidor. Diário Oficial da União,
Podemos observar que alguns pontos de discussão são julgados em favor dos incorporadores; outros, em favor dos consumidores, quando analisamos a validade da cláusula de prorrogação, a devolução da comissão de corretagem (entendimentos a favor e contrários), indenizações por danos emergentes (lucros cessantes, aluguéis, parcelas pagas à integralidade, perdas e danos), cláusula de decaimento, além do deferimento, ou não, de danos morais, dependendo do caso.

O nosso objetivo não é esgotar a discussão, muito pelo contrário. É, sim, alertar aos interessados e compromissados com esse tipo de contratação sobre o tamanho da responsabilidade assumida. Sela pelo incorporador, na entrega e prazo exatos com o que foi contratado com o consumidor; seja este, quando ausente motivos para a rescisão pela outra parte, na plena observação de suas obrigações, tais como pagar pontualmente as parcelas assumidas.
Poder Executivo, Brasília, DF, 11 set. 1990. Disponível em: <http:// www.planalto.gov.br/ccivil_03/ Leis/L8078.htm>. Acesso em: 29 abr. 2013.

Constituição Federal. Diário Oficial da União, Poder Executivo, Brasília, DF, 05 out. 
1988. Disponível em: <http:// www.planalto.gov.br/ccivil_03/ Constituicao/Constituicao.htm>. Acesso em: 29 abr. 2013. . $L E I N^{\circ} 4.591, D E 16 D E D E-$ ZEMBRO DE 1964. Diário Oficial da União, Poder Executivo, Brasília, DF, 16 dez. 1964. Disponível em: <http://www.planalto.gov.br/ccivil_03/Leis/L4591. htm>. Acesso em: 11 jul. 2013.

FILHO, Sérgio Cavalieri. Programa de direito do consumidor. 3. ed. São Paulo: Atlas, 2010. - Programa de responsabilidade civil. 8. ed. São Paulo: Atlas, 2009.
GONÇALVES, Carlos Roberto. Responsabilidade civil. 14. ed., São Paulo: Saraiva, 2012.

MARQUES, Cláudia Lima; BENJAMIN, Antônio Herman V.; MIRAGEM, Bruno. Comentários ao Código de Defesa do Consumidor. 3. ed. São Paulo: Revista dos Tribunais, 2010.

MEIRELLES, Hely Lopes. Direito de construir. 3. ed. São Paulo: Malheiros, 2011.

MIRAGEM, Bruno. Curso de direito do consumidor. 3. ed. São Paulo: Revista dos Tribunais, 2012.

RIZZARDO, Arnaldo. Condomínio edilício e incorporação imobiliária. 2. ed. Rio de Janeiro: Forense, 2012. 